UDC 821.163.41-14.09 Crnjanski M. https://doi.org/10.18485/ms_zmss.2021.99.13

\author{
Леон Којен \\ Универзитет у Београду \\ Филозофски факултет \\ 1kojen@mac.com \\ Leon Kojen \\ University of Belgrade \\ Faculty of Philosophy \\ 1kojen@mac.com
}

\title{
ПЕСНИЧКА СЕМАНТИКА У СРПСКОМ МОДЕРНИЗМУ: СТРАЖИЛОВО МИЛОША ЦРЬАНСКОГ
}

\section{POETRY-SPECIFIC SEMANTICS IN SERBIAN MODERNISM: CRNJANSKI'S STRAŽILOVO}

\begin{abstract}
У овом раду испитује се употреба фигуративног језика у поеми Сӣражилово Милоша Црњанског и први пут се идентификује карактеристичан поступак којим Црњански, истанчано варирирајући метафорично тежиште више пута поновљене исте речи, својим метафорама даје изузетно богат и нијансиран смисао.

Кључне речи: песничка семантика, Милош Црњански, Сӣражилово , фигуративни језик, метафора.

This paper examines the use of figurative language in the long poem Stražilovo (216 lines) by Miloš Crnjanski, one of the leading Serbian modernist poets, and identifies for the first time the characteristic procedure by which Crnjanski, by subtly modifying the metaphorical import of the same repeatedly used word, gives to his metaphors an unsuspected richness of meaning.
\end{abstract}

Key words: Poetry-specific semantics, Miloš Crnjanski, Stražilovo, figurative language, metaphor.

Израз „песничка семантика“ углавном се користи да означи семантичке одлике својствене песничком насупрот прозном или дискурзивном језику. Које ће то одлике бити зависи од схватања песничког језика онога ко се служи тим изразом, а често се догађа да се оне изричито не идентификују већ се читаоцу оставља да сам закључи на које се тачно одлике мисли. Ово одсуство прецизности не мора бити недостатак, поготову ако аутор само указује на чињеницу да се песнички језик разликује од прозног или дискурзивног и у семантичкој равни. Али, ја овде том изразу дајем релативно прецизно значење, узимајући - бар за потребе анализе 
модерне поезије 1 — да се песничка семантика првенствено конституише деловањем трију основних чинилаца.

Ти чиниоци су, иррво, начин на који се песник односи према семантичким правилима чије је поштовање неопходно да би појединачне реченице (односно њима изражени искази) имале кохерентно значење. Када

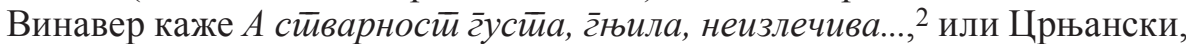
на крају „Суматре““, И милујемо gалека брgа/ и леgене горе, благ̄о, руком, ${ }^{3}$

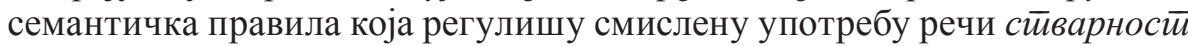
односно израза миловатии руком очигледно су прекршена. Винаверов стих приписује стварности, нечему што није опипљиво, конкретно и појединачно, својства таквих ствари и појава, док стихови Црњанског кажу о људској руци да милује нешто с чим није у непосредном физичком додиру. У делокруг песничке семантике улазе сва оваква огрешења о семантичка правила као и то како се препознавањем употребљене фигуре (метафоре, метонимије, итд) неутралише њихов ефекат и дати исказ у песми добија кохерентан смисао.

Основна семантичка правила тичу се услова који морају бити задовољени да би се, с датим лексичким јединицама, добио кохерентан исказ. Њихов домен важења је једна реченица односно исказ, али она нам ништа не говоре о томе како се више исказа повезује у веће кохерентне јединице, у дискурсе или текстове. Кохерентност таквих већих јединица обезбеђује се посебним правилима (на пример, анафоре и катафоре, лексичке кохезије, употребе деиктичких речи, просторне и временске спецификације говорног или наративног контекста, елипсе, итд). Начин на који се песник односи према таквим, дискурсним правилима gруг̄u је чинилац који улази у песничку семантику. У поезији се та правила најчешће аутоматски поштују, као и било где другде где се смислено служимо језиком. Али не мора увек бити тако. У надреалистичким песмама, рецимо у „Мутном лову у бистрој води" Душана Матића, дискурсне нити покидане су на више места, као што има песама у којима су дискурсне споне смишљено истакнуте, као рецимо у поеми Црњанског којој је посвећен овај рад.

Најзад, $\bar{u} р е ћ u$ чинилац који улази у песничку семантику је начин на који песник ритмичком организацијом своје песме утиче на њен смисао. Дејство овог фактора је очигледно, без обзира на то да ли је у вредносном погледу позитивно или негативно: као што успела, довољно само-

1 Кад говорим о модерној поезији, начелно мислим на поезију од Бодлеровог времена до данас. Истовремено, остављам отвореним питање да ли је исти тип анализе без икаквих модификација применљив и на ранију поезију (рецимо, барокну, класицистичку или романтичарску), као и питање да ли у овом контексту има разлога правити разлику између модерне и постмодерне поезије.

2 Ово је последњи стих Винаверове песме „Соната - триптихон Растка Петровића“, објављене у загребачком часопису Крийика у лето 1921. године. В. Vinaver 1921: 257. Цео „триптихон“ касније је укључен у Винаверову збирку Чувари свет̄а (1926).

3 „Суматра“ је први пут објављена у четвртом броју нове серије Срйског̄ књижевног̄ г̆ласника, 15. октобра 1920. године. В. Црњански 1920b: 262. 
својна ритмичка организација чини смисао далеко истанчанијим него што би то био без ње, тако га истрошен, већ ,аутоматизован” ритам чини неоригиналним и баналним. Наравно, утицај који ритам има на смисао далеко је лакше констатовати него објаснити, али ако га не бисмо узели у обзир наше схватање песничке семантике било би битно осиромашено. У модерној српској поезији управо је Сйражилово Црњанског један од најбољих доказа колико особена ритмичка организација може да унесе у текст неслућене смисаоне нијансе и да да̂ непоновљив карактер емоцији која у овом или оном облику представља једно од општих места западне песничке традиције.

У једном од првих манифеста српског модернизма, „Објашњењу 'Суматре'“ из 1920. године, налази се и следећа, по много чему кључна реченица: „Ослободили смо језик од баналних окова и слушамо га како нам, слободан, он сам открива своје тајне.“4 „Банални окови“ су пре свега правила везаног стиха оличеног у Ракићевој и Дучићевој версификацији, јер овом реченицом Црњански закључује свој пледоаје за слободни стих. Али оно што он каже одмах затим — „Није давно да је Дучић исмејан, усудио се да напише 'Шуште звезде'. Ми, разуме се, одосмо даље“ - показује да се реченица о ослобађању језика не односи само на ритмичке каноне него и на песничку семантику. Црњански нема у виду само замену везаног слободним стихом него и много обухватнију обнову изражајних средстава у српском песништву. Чини ми се да каснији критичари и историчари књижевности нису искористили путоказ који им је својом тврдњом о ослобађању језика дао Црњански: о специфичним новинама које су на плану песничке семантике донели најважнији модернистички песници до данас није много писано. Овај рад допринос је проучавању тог питања, једног од најважнијих за разумевање великог периода обнове изражајних средстава у српском песништву двадесетих и тридесетих година прошлог века. ${ }^{5}$

Овде ће бити речи само о једном аспекту песничке семантике у Сйражилову: о фигуративном језику у овој поеми, о томе како Црњански неутралише огрешења о семантичка правила да би својим фигурама дао не само кохерентан смисао него и особене квалитете које препознаје сваки познавалац српске поезије. ${ }^{6}$ Разматрање других двају аспеката

4 „Објашњење 'Суматре““ Црњански је објавио заједно са „Суматром” у истом броју Срйског̄ књижевног̄ глласника. В. Црњански 1920с: 267.

5 У овом раду ослањам се на схватање модернизма у европској и српској поезији које сам сажето изнео у предговору свом избору из поезије Растка Петровића, Милана Дединца и Душана Матића. В. Којен 2020: V-XII.

6 Што, наравно, не значи да је у стању да их тачно именује или колико-толико прецизно одреди. 
те семантике, и самих по себи и у њиховом односу са фигуративношћу, мора остати за другу прилику: овде ћемо их се дотаћи само уколико је то неопходно да би се разумео начин на који се Црњански у Сйражилову служи фигуративним језиком.

Када говоримо о овом питању, мислим да треба почети од једног запажања на које недвосмислено упућује критичка рецепција $C \bar{u} р а ж и-$ лова и које, чини ми се, потврђује и читалачко искуство. Што год били склони да кажемо о њима када их разматрамо истргнуте из контекста, метафоре и друге фигуре у Сйражилову - рекло би се још од времена када је поема објављена — не стварају никакву тешкоћу при разумевању иоле упућеним читаоцима српске поезије. У поређењу с фигуративним језиком у Ойкровењу Растка Петровића, ${ }^{7}$ да и не говоримо о надреалистичким песмама као што су „Успавака као поредити“ Марка Ристића или „Мутан лов у бистрој води“, „Заменице смрти“ и „Теку реке“ Душана Матића, фигуративни језик Сш̄ражилова у смисаоном погледу делује готово прозирно.

Ако се сложимо с овим запажањем, поставља нам се питање зашто је тако. Фигуре у Сйражилову не делују нам разумљиво захваљујући традицији: напротив, оне су потпуно нове у односу на лирски језик претходне генерације српских песника, у читавом њеном распону од Ракића и Дучића до Пандуровића и Диса. Нити би се могло рећи да су нам оне разумљиве захваљујући блискости са здраворазумским начином мишљења и доживљавања: сензибилитет Црњанског, који се савршено огледа у његовим фигурама, нема у себи готово ничег здраворазумског. Чиме се онда објашњава да нам, док читамо Сйражилово, оне изгледају лако схватљиве, једва издвојене у односу на стихове где фигура уопште нема? Саме по себи, истргнуте из контекста, оне уопште не остављају такав утисак: 8

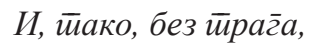
расуће ми руке жива йела мојих gраг̄a.

И, тиако, без врена, за мном ће живой у йрешње gа се мења.

7 Рецимо, у песмама „Зимски репертоар“ или „Преиначења“.

8 Сйражилово наводим и разматрам у првој потпуној верзији, објављеној у часопису Пуйеви фебруара 1922. године. В. Црњански 1922а: 3-9. Та верзија се у неколико појединости разликује од коначне, први пут објављене 1954. у париском издању Ogaбраних сииихова Црњанског. Како је овај рад део ширег истраживања које се бави настанком и еволуцијом српског модернизма, ипак сам се определио за њу да би се добила што вернија историјска слика о овом кључном раздобљу у историји српске поезије. Наводећи текст из Пуйева исправио сам више или мање очигледне штампарске грешке и минимално га прилагодио данашњем правопису; у погледу интерпункције, у малом броју случајева изоставио сам запете, по правилу тамо где их је касније изоставио сам Црњански. 
И, йако, без имена,

истиом жалощћу милујем бряа невиђена.

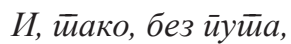

и моје миловање, ӣо умирању, луйа.

Измештена из свог природног окружења, свака од ове четири фигуре опире се тумачењу и смисаоно остаје мање-више непрозирна. Руке

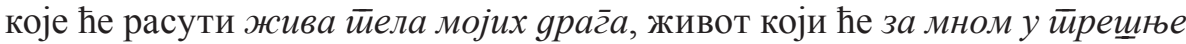
gа се мењ $а$, ,ја“ које исйом жалощћу милује бряа невићена, моје миловање које йо умирању луй $а$ - када их посматрамо изван контекста, нејасно је шта ове слике значе и како се неутралишу очигледна огрешења о семантичка правила тако да стихови добију кохерентан смисао. Уместо да нешто разјасни, први стих у сва четири случаја (И, йако, без...) као да само додатно отежава тумачење.

Сйражилово је у ритмичком и строфичком погледу до детаља изграђена целина, коју чини шест једнаких делова од по седам строфа, написаних у слободном стиху са интонационом доминантом и допунском улогом риме. ${ }^{9}$ Сваки од тих делова има исту строфичну и римовну организацију: квинта $(a, b, c, b, b)$, затим септима $(a, b, a, b, c, d, c)$, септима $(a, b, c, d, c, d, b)$, катрен наизменично кратких и дужих стихова $(a, a, b, b)$, катрен дужих стихова $(a, b, a, b)$, катрен наизменично кратких и дужих стихова $(a, a, b, b)$ и опет квинта $(a, b, c, b, b)$. Али, то није све. Сйражилово и као текст има утврђену, назовимо је реторичку структуру: сваки од шест делова поеме састављен је од седам реченичних целина, то јест строфа, ${ }^{10}$ од којих је свака (с понеким изузетком) синтаксички а делом и семантички паралелна одговарајућим строфама преосталих пет делова.

Ова трострука организација - ритмичка, строфичка и реторичка уочљива је већ на први поглед а спроведена је тако да делује јединствено и ниједног тренутка не оставља утисак нечег траженог. На њу је свакако мислио Марко Ристић када је рекао о Сйражилову да „видна и за једну лирску поему заиста монументална архитектура нимало не противречи необичној музикалности, певајућој мекоћи, лирској носталгичности нежног осећајног материјала од кога је саграђена“.11 Но, постојање ове бриљантно остварене тројаке организације, где су „елементи спонтаности и инспирације“ нашли савршен склад са „елементима смишљености и конструкције“" 12 учинило је да у досадашњој литератури о Cӣражилову није поклоњено довољно пажње једном далеко мање приметном али зато ништа мање важном фактору.

9 За сажет опис версификације Црњанског у Сйражилову, в. Којен 1998: 31-33, $81-83,127-128$.

10 Последња строфа сваког дела без измена понавља прву.

11 Ristić 1957: 776.

12 Како је тачно казао Ристић, Ibid., стр. 776. 
Наиме, колико год се с правом дивили овој мајсторској организацији и веровали да поема њој дугује део своје непоновљиве лепоте, позивање на њу неће нам објаснити начин на који се Црњански у Сйражилову служи фигуративним језиком. Штавише, ако мислимо да лепота ове поеме није у свему аналогна лепоти неке музичке композиције, рецимо Бахових „Голдбергових варијација“ или Моцартовог клавирског концерта у це-молу (К. 491), већ зависи и од смисла читавог сплета фигура које се провлаче кроз њу од прве до последње строфе, питање шта је особено за фигуративни језик Црњанског једно је од кључних која нам се постављају у вези са Сйражиловом.

Ово питање тим је важније што се о њему досад није много расправљало и што је услед тога наша слика о песничкој семантици Црњанског и уопште српског модернизма остала суштински непотпуна. У ономе што је писано о Сйражилову, бар колико је мени познато, нема правог покушаја да се анализира како Црњански и у равни фигуративног језика мири „елементе инспирације“ са „елементима конструкције“, другим речима нема покушаја да се опише йосйуйак којим се у Сйражилову неутралишу огрешења о семантичка правила а стихови који их садрже добијају кохерентан смисао. Неки традиционално настројени критичари и историчари књижевности вероватно би рекли да се о таквим поступцима уопште не може говорити и да је потрага за њима узалудан посао. Бесумње, као и у многим другим случајевима (рецимо, када је посреди структура стиха), то су поступци којих се песници много више прећутно придржавају него што их свесно примењују. Али са́мо њихово постојање не изгледа ми подложно сумњи. Ако се може показати како они функционишу у песничким текстовима, то ће бити најбољи одговор скептицима који их доводе у питање.

Пре но што покушам да то учиним на примеру Сйражилова, задржаћу се на Винаверовом стиху који сам већ навео као пример фигуративног језика на почетку овог рада:

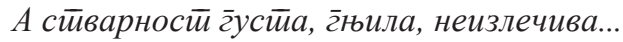

У овом стиху изузетне концизности и значењског богатства налазимо исти поступак који је Црњански у много ширем контексту применио у Сйражилову. У њему се ${ }^{13}$ стварност замишља као суштински одређена својствима густих, гњилих, неизлечивих ствари: дакле, као нешто што нас са свих страна окружује не допуштајући могућност излаза (попут густе, непробојне масе или густе, непроходне шуме), као нешто што је оличење пропасти и распадања (попут презрелог, гњилог плода), као нешто чему се узалуд одупиремо јер ће надвладати сваки наш отпор (попут тешке, неизлечиве болести). Смисао читавог стиха конституише

13 Анализу која следи у основним цртама сам преузео из једног ранијег рада. В. Којен 1986: 15-16. 
се истовременим деловањем ових трију простих атрибутивних метафора (типа , $S$ је $P$ “) и њиховим спајањем у сложенију целину, која нам предочава стварност кроз три наизглед различита а ипак суштински идентична аспекта. Тој прећутној идентификацији - без које би стих имао мање парадоксалан и мање прегнантнан смисао - свакако највише доприноси привативни придев неизлечив, последњи од трију атрибута приписаних стварности. Делом због свог завршног положаја у стиху, а још више због свог максимално суженог но ипак асоцијацијама богатог семантичког поља, он пресудно утиче на смисао других двеју, потенцијално много двосмисленијих метафора. Наиме, увлачећи преостала два атрибута у своју семантичку сферу, он као да преноси на њих део властитог значења, па стога — ако је моја приближна парафраза тачна — придев $\bar{z} y c \bar{u}$ тако емфатично уводи идеју безизлазности, а придев г̄њио идеју пропасти и распадања, истовремено пригушујући друге семантичке асоцијације тих двају придева које би, ако би биле активиране, онемогућиле да стих добије овакав смисао.

Винаверов стих одличан је пример како се заједничким деловањем више једноставних метафора, од којих се свака тумачи сагласно са другима, неутралише ефекат вишеструког огрешења о семантичка правила и, као резултанта, добија сложенији, нијансама богат смисао који измиче исцрној парафрази. Ако у први мах не осетимо све богатство тог смисла, довољно је упоредити цео стих са изолованим, семантички неупоредиво непрозирнијим атрибуцијама као што су „Стварност је густа“ или „Стварност је гњила“, па и „Стварност је неизлечива“; када то учинимо, биће нам јасније шта је све постигао Винавер комбинујући у једном стиху ова три придева, уз троструко кршење семантичких правила.

Истовремено, овај стих је још једна потврда колико је погрешно традиционално схватање које сваку метафору (метонимију, итд) види као замену једног израза неким другим. По том схватању, реченицу кохерентног значења у којој су све речи употребљене дословно говорни субјект из овог или оног разлога (да би се изразио упечатљивије, економичније, итд) замењује другом која садржи неко огрешење о семантичка правила; онај ко исправно схвата ту другу реченицу врши исту замену у обрнутом правцу и тако се опет добија реченица кохерентног значења. ${ }^{14}$ Сигурно је да у свакодневном говору постоје и овакви или бар приближно овакви случајеви. Али, ако би се тражило да извршимо сличну операцију са Винаверовим стихом (или малочас наведеним стиховима из Сйражилова), па и са многим метафорама из свакодневног говора, лако је видети да би то био потпуно јалов посао.

14 Рецимо, неко би могао рећи „Ана је права змија” уместо да каже „Ана је лукава, подмукла и опасна“ (,опасна“у у значењу „неко кога се треба чувати“). По традиционалном схватању, то би значило да израз йрава змија добија „метафорично значење“ лукава, йодмукла и ойасна. 
Другим речима, само се избледеле, готово лексикализоване метафоре (метонимије, итд) могу анализирати у равни реченичног̄ значења, које је функција значења речи које чине дату реченицу и начина њиховог синтаксичког комбиновања. Речено сосировским језиком, праве метафоре (метонимије, итд) не јављају се у равни језичког система (langue) него у равни говора (parole): служећи се овом или оном реченицом, говорно лице или аутор текста саопштава одређен смисао, који зависи како од значења употребљене реченице тако и од низа других релевантних околности.

Категоријалну истину да се метафора и сродне фигуре јављају у равни смисла који се саопштава у некој појединачној прилици, a не у равни апстрактног реченичног значења, ${ }^{15}$ посебно треба имати на уму када се бавимо фигуративним језиком у поезији. Улогу релевантних околности које, уз значење употребљене реченице, одређују шта је у датом случају њом саопштено, шта је њен смисао, овде има контекст у којем се она јавља: то ће по правилу бити њено непосредно окружење у склопу песме и, у крајњој линији, песма у целини. Имајући ово у виду,

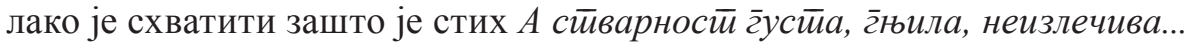
тако јасан пример семантичког поступка којим су се, свако на свој начин, служили и Винавер и Црњански: он нам показује како се, у оквиру само јеgног̄ стиха, заједничким, сагласним деловањем више једноставнијих метафора потпуно неутралише ефекат огрешења о семантичка правила. ${ }^{16}$ У Сйражилову, насупрот томе, бар ако погледамо досад наведене примере, то се постиже тек у контексту који непосредно чини вище стиихова из различитих строфа, увек из вище но јеgног дела поеме, а неки од тих стихова садрже и алузије на друге песнике или на претходна дела Црњанског.

\section{II}

Због ове разуђености релевантних контекста добро је почети анализу фигуративног језика у Cйражилову једним запажањем које сведочи о томе како је сам Црњански гледао на своју поему у време њеног настајања. Знамо да је Сйражилово најпре било објављено у деловима, у Мисли, загребачкој Критииии и Срииском књижевном глласнику, па тек онда као целина у Пуиеевима Милана Дединца и Марка Ристића фебруара 1922. године. У Мисли су се септембра 1921. појавила прва два дела поеме, у двоброју Крийике за новембар и децембар исте године трећи и четврти део, а два завршна дела изашла су 1. јануара 1922. у Срйском 76-116.

15 Класично филозофско образложење те истине дао је Џон Серл. В. Searle 1979:

16 То је могуће пре свега зато што тај стих закључује целу трочлану „Сонату“, постављајући се као самостална антитеза свему што му је претходило. 
књижевном глласнику. ${ }^{17}$ У Мисли и Крийици испод наслова Сйражилово стајало је у загради „одломак“, а вероватно је само уреднички пропуст што те назнаке нема и у Гласнику. Упркос томе, сама чињеница самосталног објављивања говори да је Црњански сваки од трију одломака сматрао значењски довољно заокруженим да не изневери смисао целе поеме и уједно способним да верно представи нову фазу његовог песништва, започету „Суматром“ и „Објашњењем “Суматре““ годину дана раније.

То потврђује и писмо Црњанског Милану Ћурчину од 15. јануара 1921, у којем му нуди (као што се показало, безуспешно) да у Новој Евройи објави цело Сйражилово. „Свакако сте читали неки одломак мога 'Стражилова'“, пише Црњански. „Први део је штампан у 'Мисли', други у 'Критици' - број 'Алфа', а трећи 1. І. у Књ. Гласнику. Сада бих волео да штампам 'Стражилово' - цело... Мада Ви ретко штампате стихове у Н. Европи - да ли би га донели у једном од идућих бројева... Овај спев је моја најдража ствар. Волео бих да репрезентујем се њиме.“18

Свестан вредности Сӣражслова, Црњански га је најпре објавио у заокруженим одломцима, свакако зато да би тиме на свој „спев“ скренуо пажњу што више читалаца, а тек потом је предузео кораке да га објави у целини. Стога верујем да подела на три веће целине, којој је прибегао сам песник представљајући своју поему читалачкој публици, тачније одсликава смисаону артикулацију Сӣражилова него неки други покушаји да се то учини. Никола Милошевић је, рецимо, унутар онога што је звао „мотивацијском мрежом” Сйражилова разликовао „пет чворних тачака“: „мотив завичаја, односно туђине“, „мотив љубави“, „мотив пијанства и смеха, односно диониски мотив уживања“, „мотив природе“ и „мотив пролазности“ ${ }^{19}$ Колико год да је могла да послужи његовом главном циљу - да покаже како мотив пролазности „представља окосницу поруке“ поеме Црњанског и да су му „сви остали мотиви на неки начин подређени“ - не изгледа ми да нам Милошевићева „мотивацијска мрежа“ може много помоћи у детаљнијој и дубљој анализи Сйражслова. Ако се држимо трочлане поделе која потиче од самог песника, тематске контуре Сйражилова оцртавају се неупоредиво јасније. ${ }^{20}$

Два уводна дела поеме нас, кроз неколико алузија, од самог почетка враћају „Суматри“ и у тој песми израженом осећању живота. Узмимо, рецимо, пету строфу првог дела, коју наводим после друге строфе „Суматре“:

17 Сва три објављена одломка - као и цео текст поеме у Пуйевима - имају на крају назнаку места и времена: „Фиезоле, маја 1921 “.

is Поповић 1984: 1601-1602.

19 Милошевић 1973: 4-11.

20 Чини ми се да овај суд остаје одржив и када се има у виду исцрпно и у многим појединостима уверљиво тумачење Сёражилова које је дао Александар Петров. В. Петров [1971] 1988: 83-108. 
Расӣужи ли нас какав блеgи лик, щйто г̄а изгуубисмо јеgно вече, знамо gа, нег̄ge, неки йойочић, месӣо юег̄a, румено йече.

$$
\text { (,Суматра“) }
$$

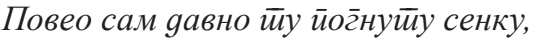

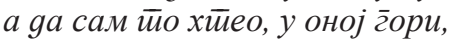
иознао гррожђе, ноћ и иееревенку,

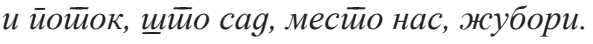

\section{(Сӣражилово)}

Алузија је и овако сасвим јасна, али је још директнија ако претпоставимо да је, у време писања Сйражилова, Црњански већ био претворио $\bar{u} о \bar{u} о ч и ћ ~ у ~ \bar{u} о \bar{u} о к,{ }^{21}$ како стоји у свим каснијим прештампавањима „Суматре“.

За разумевање Сӣражилова још су важније алузије на трећу строфу „Суматре“, у којој се први пут у поезији Црњанског повезују трешње и завичај:

По јеgна љубав, јут̄ро, у йућини, gушу нам увија, све йешње, бескрајним миром йлавих мора, из којих ирвене зрна корала, као из завичаја ӣрещње.

Симболична веза између трешања и завичаја у Сйражилову се наговештава већ од прве строфе, али и она је само део алузија на прозни текст у склопу „Објашњења 'Суматре'“, где се описује један доживљај Црњанског на повратку из рата (путовање возом у завичај, неочекивани сусрет са другом на загребачкој железничкој станици, размишљања и расположења изазвана тим сусретом) и уједно изражава оно осећање живота које је убрзо названо суматраизмом. Из тог прозног текста наводим само она места која ми, било непосредно било нешто посредније, изгледају важна за разумевање Сйражилова:

„Мир, мир зоре полако се спуштао у мене... Одједном ја се сетих градова и људи, што сам их видео на повратку у завичај и, први пут, приметих неку огромну промену.

21 То ми изгледа сасвим могуће управо зато што би се тиме на овом месту добио потпуни паралелизам између „Суматре“ и Сйражилова. У „Објашњењу “Суматре”” јављају се обе речи, и йойочић и йойок: „Чуо сам неки поточић да жубори. Мучио сам се да га сагледам, кроз мрачно грање, а кад га нађох, он ми се учини весео и румен. $<. .>$ Обузе ме једна тешка слабост... и ја помислих: гле, како никаквих веза нема у свету... Ништа не може да се задржи, па и ја где све нисам стигао. А овде, ето, како весело тече овај поток. Он је румен, он жубори. <..> И жалост и бледо лице и све моје мисли ишчезоше и утопише се лагано у жубору тога потока" (Црњански 1920c: 269). Док је писао наведену строфу Сйражилова, Црњанском је морао бити у свести, или бар у сећању, и овај одломак из „Објашњења 'Суматре'“. 
[...] Изнурен и сам, сео сам у један мрачан кут, сам самцит, неколико пута рекао сам тихо самом себи: Суматра, Суматра...

Све је то тако замршено. Воз је пошао и тутњао. Успављивао ме је у мислима да је то тако необично, тај живот са огромним даљинама у себи. Куд све нису стигли наши боли; шта све нисмо уморно помиловали у туђини. И не ја, не он, десеторица, хиљада, него милиони. Помислих како ме чека завичај. Знам, трешње су свакако већ румене, а села су сад весела. Гле, како су боје, чак до звезда, исте, и трешања и корала; како је све у вези на свету. Суматра - рекох, опет, подругљиво, самом себи.

$[\ldots]$

Али, дубоко, у души, крај свег опирања, ја сам осећао, одједном, неизмерну љубав према тим далеким брдима, снежним горама, чак горе до ледених мора. Осетио сам неизмерне даљине, до тих, румених острва, где се догађа оно што смо, можда, ми учинили; изгубио сам страх од смрти, везе за околину нашу, и као у некој лудој халуцинацији дизао сам се у те безмерне јутарње магле, да испружим руку и помилујем далеки, високи Урал, мора индијска, куд је отишла румен са мога лица, острва, љубави, заборављене бледе прилике... И сва та замршеност постаде један огроман мир и безгранична утеха." 22

Суматраистичко осећање живота - како је исказано и овде, и у самој „Суматри”, и другде у поезији и прози Црњанског с почетка двадесетих година прошлог века - нескривено је ирационално и не претендује да буде ништа друго. То је бесумње разлог што су многи пишући о Црњанском (рецимо, Марко Ристић) више истицали да се то осећање јавило као реакција на године проведене у кланици Првог светског рата и посматрали га из тог угла него што их је оно занимало са́мо по себи и као елемент поетског света „Суматре“ и Сйражилова. Бар када је реч о ова два дела, ${ }^{23}$ за такав став нема правог оправдања: ни „Суматру“ ни Сйражилово нећемо исправно разумети ако у суматраизму будемо видели само једну од могућих реакција на нехуманост и бесмисао Великог рата.

За разлику од „Суматре“ и „Посланице из Париза“, где је као осећање апсолутно доминантан, суматраизам у Сйражилову у сталном је контрапункту са слутњом сопственог краја и свешћу о пролазности. То се врло јасно види ако узмемо да је Сйражилово смисаоно артикулисано у три веће целине, назначене њиховим самосталним објављивањем. Из једне од тих целина у другу, однос између ових двају егзистенцијалних расположења ${ }^{24}$ стално се мења и та динамика основна је тематска нит на чијој се позадини конституише смисао целе поеме.

22 Црњански 1920с: 269-270.

23 Исто важи и за „Посланицу из Париза“, написану између „Суматре“ и Сӣpaжилова, која је нека врста суматраистичког манифеста у стиху. Овде пре свега мислим на њену прву, мање познату верзију, објављену у Зенийу, у време краткотрајне сарадње београдских модерниста са Љубомиром Мицићем. B. Crnjanski 1921a: 2.

24 Назовимо их тако да бисмо истакли да у Сйражилову свако од њих представља спој мисли, осећања и утисака несводљив на само један од тих елемената. 
Прва целина пуна је слутњи и ишчекивања, а оба егзистенцијална расположења пре су наговештена него јасно исказана:

Луйам, јощи, виииак, са сребрним луком, расиветйане йрещње, из засеgа, мамим; али, иза горая, завичај већ слуииим, żge ћy смех, йоg јаблановима самим, gа сахраним.

И, йако, већ слуйим, gа ћу, скоро, gушу сасвим gа йомуйим. И, йако, већ живим, збуњен, наg рекама овим, голубијски сивим.

И, йако, без веза, сиииже ме, ийак, родна, болна језа. И, йако, без дома, ийак ће ми судба йосӣайи йит̄ома.

Већ gавно, ириметиих, gа се све разлива, щийо на бряа зияам, из воgа и облака, и, кроз неку жалости, иеек млаgощћу дошлом, gа ме љубав слаби, до слабосиии зрака, ировияна и лака.

Строфе које сам цитирао нека су врста оквира ${ }^{25}$ у којем се на тренутак нешто јасније исказују слутња о сопственом крају и, насупрот њој, суматраистичко осећање „огромног мира“:

И, местио gа се клањам Месеиу, иосканском,

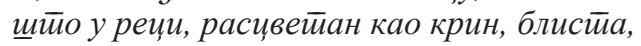
знам gа ћу, овог ирролећа, закащљаиии ружно и вияим вийак сйас, йреgа мном, ийо се рони, верно и йужно, сенком и кораком, кроз воgу щйо звони, у небеса чистй.

И, месиио gа воgим, иоогелеgом зеленим, као ирре, реку шийо се слива; gа скачем, као Месеи, ио горама иуусиим и зажарене шуме gа йоййирим, саg, йлавим и гуссиим, снегом и леgом, смещећи се, мирим све иими се збива.

25 То су строфе које отварају и затварају прву већу целину (= први и други део поеме) и средње, то јест четврте строфе првог односно другог дела. 
Ипак, ни та слутња ни то осећање као да нису до краја изречени: прва целина сва је у знаку нечега што тек има да се деси, а што је само метафорично одређено (г̈gе ћу смех, йоg јаблановима самим, / ga сахраним) или посредно наговештено (gа ме љубав слаби, gо слабосиии зрака, / йровияна и лака). У другој и трећој већој целини (= трећем и четвртом односно петом и шестом делу поеме) оба егзистенцијална расположења далеко су недвосмисленије изражена, а њихов однос неупоредиво је сложенији него на почетку. У другој целини, суматраистичко осећање као да се бори за превласт са свешћу о пролазности и слутњом сопственог краја, док је у трећој целини - ако останемо при истој метафори та битка изгубљена. „Ја“ које је умело да каже И йако, без врења, / за мном ће животи у йрещњ gа се мена сада говори суштински друкчијим језиком: али, йолако, саg већ јасно, слуйим, / gа умирем и ја, са gyхом йотиамнелим, / иешким, невеселим и, још емфатичније, али, йолако,

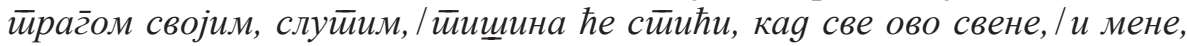
и мене. Свест о смрти превагнула је над екстатичним суматраизмом.

\section{III}

Смисаона артикулација Сйражилова на три веће целине и за њу везано сучељавање свести о пролазности и слутње сопственог краја са суматраистичким осећањем живота нису, наравно, крајња него почетна тачка тумачења. Поема Црњанског не би било једно од највећих остварења модерне српске поезије када се не би опирала сваком покушају да јој се смисао исцрпе неком интерпретативном формулом, па макар и таквом која нам више од других отвара пут ка исправном тумачењу. Разлоге тог опирања не треба тражити само у неоспорном, готово очигледном утицају ритма на смисао: досадашњи тумачи Сйражилова углавном су превидели колико начин на који се Црњански служи фигуративним језиком доприноси не само смисаоном богатству и истанчаности него и непоновљивој лепоти његове поеме.

Какав је однос између сталног сучељавања двају наизглед потпуно опречних егзистенцијалних расположења и читавог сплета фигура чији смисао постаје све сложенији како смо ближи крају поеме? Почнимо са једном фигуром у последњем делу поеме која је док читамо готово неприметна:

А мир, свуg је мир, кая расиеем щито је било и ириклоним гллаву, на оно, шитио ме чека: на цеео јеgан крај, са ког̄ се вино слило, и смех, и gивна бесииияносй далека.

Без обзира што се у читању лако прелази преко тога, јасно је да су у првом стиху прекршена семантичка правила. Цео контекст нам говори да се израз щйио је било односи на прошлост песничког ,ја“, а прошлости 
се можемо сећати или је заборавити, можемо јој се вратити у мислима или покушати да не мислимо на њу, али је сигурно не можемо расути: каg расием щйо је било може бити смисаоно кохерентан израз само ако је расиеем употребљено метафорично. Ако у читању једва да осећамо разлику између метафоре у каg расием иㅡㅇ је било и обичног преносног значења у йриклоним гллаву, на оно, щимио ме чека, ${ }^{26}$ то је зато што је смисао метафоричног расием одређен сагласним деловањем ранијих метафора с истом речју.

Оне се најпре јављају у неколико међусобно не сувише удаљених строфа другог и трећег дела поеме, заједно с поменом жуйог̄ лищћа као симбола пролазности:27

Не, нисам, йре рођења, знао ни јеgну ӣуг̄y;

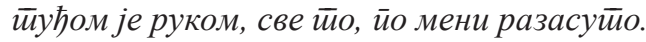
Знам, иолако ияем у јеgну йайњу gугу и, знам, йог̄нућу гллаву, кая лищће буде жуйо.

Луйам, јоми, витиак, йо мостиовима йућим, на мирисне реке, иррилежем, йа ћуииим; али, йоg воgама, завичај већ вияим, ойкуд йођох, иоосуй лищћем жуйим и расуйим.

А, местио свог̄ животй, gавно живим буре и сенке гेрозних виног̄paga.

Насииављам суgбу, већ и коя нас йрощлу, болесну неку млаяости, без иррестианка, иеке рођењем домлу, са расуйим лищћем, щитол, са грроба Бранка, на мој животи йaga.

Симболична вредност жуйог̄ лищћћ у овим строфама могла би се осетити чак и да се не препознају две комплементарне алузије, најважније у целој поеми ако изузмемо оне на дела самог Црњанског. На прву од њих указује сам текст, помињањем Бранковог гроба; реч је, наравно, о почетним стиховима песме „Кад млидијах умрети“: Лисје жутии веће йо gрвећу, / Лисје жуйо gоле веће йаgа, / Зеленог̄а вище ја никаgа / Виgей нећу. Друга алузија није експлицитно назначена, али је ипак очигледна за иоле упућеног читаоца. Реч је о чувеним стиховима о пролазности људског живота из шестог певања Илијаge:

Какав је лищћу роя, и љуямма је уйраво йакав:

Јеgно йо земљи лищће разбаиује вјетиар, а друг̄о

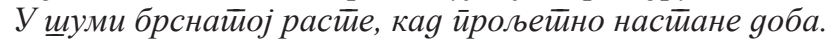

Тако и љууди јеgни осйјјевају, а друг̄и г̄ину.

26 „Приклонити главу“ у преносном значењу „помирити се (са нечим)“.

27 Глагол разасуйи у првој наведеној строфи и значењем и звучањем варијанта је глагола расуйи. 
Навео сам ове стихове у Маретићевом преводу, ${ }^{28}$ који је Црњански вероватно познавао у младости, и није искључено да стихови о Бранко-

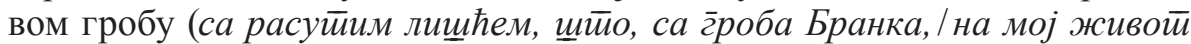
$\bar{u}$ aga) садрже и реминисценцију на Хомерово Јеgно йо земљи лищће

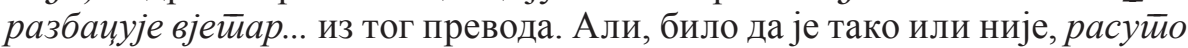
лищће овде је двојак симбол пролазности: пролазности појединачног живота, Бранковог и онога „ја“" које се сећа Бранка и његовог гроба, и пролазности људског живота као таквог (Какав је лищћy pog, и љуgма је уйраво йакав). Комплементарност ових алузија добар је пример изузетне а готово неприметне вештине с којом је остварена песничка замисао Сйражилова.

Исто би се могло рећи и за начин на који се јављају фигуре с глаго-

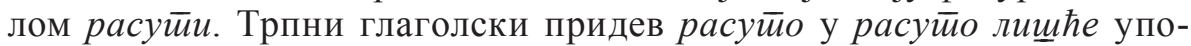
требљен је метафорично, јер - бар према речничкој дефиницији ${ }^{29}$ расуйи означава радњу која подразумева свесног актера; али то је сасвим избледела метафора, која нам у контексту Сйражилова говори о пролазности исто онако како то чине дословни изрази жуйо лищће и свело лищће. Тај глагол се затим јавља у четвртом делу поеме, где стиховима али, свиснућу, йо и овgе слуииим,/за гоомилом оном, јеgном, gавно, млаgом/ йog сремским виногрраgом почиње чулношћу прожета евокација

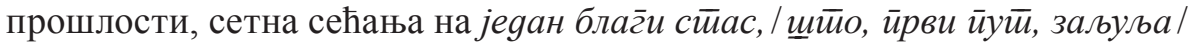

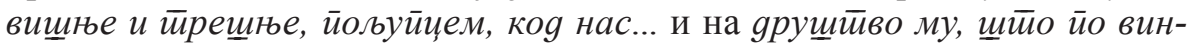
ском меху, / свело лищће расу, са осмехом муйним, / ирескачући, ирви йуй, йоиоке, у смеху. Овде је глагол једини пут употребљен дословно, јер у наредне две строфе расух односно расуће има пуну метафоричну вредност:

A, местио свог̄ живойа, знам gа, йо вияику,

йај смех расух, наg сваким иеллом голим...

И, йако, без речи,

gух ће мој све ииуђе смрӣи gа залечи.

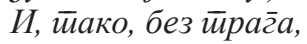

расуће ми руке жива иемла мојих gраг̄a.

У овом преласку са дословног значења (за gрущйво му, щйио... свело лищће расу... иррескачући, иррви йуй, йойоке, у смеху) најпре на класично стилизовану ( $\bar{u} a j$ cмex pacyx) а затим на много модернију метафору (pacyћe ми руке жива йела мојих gраг̄a) има нечег врло карактеристичног за цео поступак Црњанског у Сйражсилову. Нескривено ирационално осећање живота какво је он имао тешко се може уверљиво изразити у поезији која не прибегава изразитим, семантички неочекиваним

28 Маретић 1905: 104. Превод ових стихова остао је неизмењен и у издању Матице хрватске из 1912. године.

29 В. Речник $M C$, s. v. расуйи. 
фигурама: такве су све средишне фигуре у Сӥражилову, па и метафоре у стиховима расуће ми руке жива йела мојих gраг̄a и А мир, свуg је мир каg расием щйо је било. Шта би оне могле да значе изван свог контекста остаје потпуно неодређено и утолико непрозирно, али у поеми Црњанског њихов смисао добрим делом је одређен ранијим употребама исте речи.

Те употребе, а пре свега традиционална слика расуйог̄ лищћ $а$ с алузијом на хомерски топос о пролазности, говоре нам да се и ове две метафоре морају тумачити с тим топосом на уму. Као што ветар носи и расипа свело лишће, које нестаје да се више не поврати, тако ће нестати да се не поврате и жива йела мојих gраг̄a, па и читава прошлост песничког субјекта, који може бити и било ко од нас: повремено јављање првог лица множине у шестом, завршном делу Сйражилова није случајно, ${ }^{30}$ као што није случајно ни што је „Суматра“ написана у првом лицу множине. Сад видимо и зашто се глагол расуйи с таквом снагом наметнуо Црњанском: захваљујући традиционалној слици расуйог̄ лищћа, он као да је створен да споји хомерски топос о пролазности људског живота и суматраистичко осећање да се човек мора помирити с тим да испуњава судбину необјашњиво одређену негде другде. Када песничко „ја“ на почетку поеме каже саg, йлавим и гуустим, / снегіом и леgом, смещећи се, мирим/ све шитио се збива, у његовим речима још се чује одјек реченице из „Објашњења 'Суматре'“: „И сва та замршеност постаде један огроман мир и безгранична утеха.” У стиху А мир, свуg је мир, каg расиеем щитио је било тај одјек се угасио. Са свешћу о пролазности коју носи у себи каg расием шимио је било, мир о којем говори песничко „ја“ више нема ништа у себи од безг̄раничне уйехе.

Истовремено, пажљивијим читаоцима неће промаћи како нас строфа која почиње овим стихом, последњим где се јавља фигура са глаголом расуй $u$, враћа структурално аналогној строфи где се та фигура јавља први пут:

Не, нисам, йре рођень, знао ни јеgну йугуу;

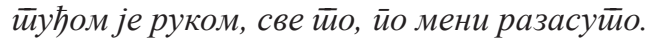

Знам, иолако ияем у јеgну йайњу gуг̄у

и, знам, йог̈нућу г̄лаву, кая лищће буgе жуйо.

А мир, свуg је мир, кая расиемм щитио је било и ириклоним гллаву, на оно, шитио ме чека: на иеео јеgан крај, са ког̄ се вино слило, и смех, и дивна бестиияности далека.

30 В. следеће стихове: $y$ живой йреg нама, / смири / и чула уйокоје и И, йако, без мора, / иррелићу живой нащ, зорама Фрущких Гора. Њима треба додати и алузију садржану у стиху и моје миловање, йо умирању, луйа на раније место из петог дела о мојој и туђој младости: виgим ga је, у раном уми-

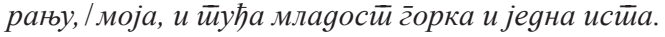


Навео сам поново обе строфе да би се лакше осетило колико идентичност ритма овде утиче на смисао, и то на сасвим одређен, прецизан начин. Њој добрим делом треба захвалити што ранија од ових строфа тако јасно антиципира крај поеме, њен пети и шести део, где свест о пролазности и слутња о сопственој смрти потпуно пригушују суматраистичко осећање живота како га знамо из ранијих делова поеме. ${ }^{31}$ То сигурно не би било могуће да се у тој строфи први пут не јавља свест о пролазности, која слутњу о сопственом крају почиње да претвара у извесност; али без ритмичког паралелизма то не би било довољно да ову строфу недвосмислено повеже са завршним деловима поеме. У том паралелизму, који је и ритмички и семантички, учествује и структурално аналогна строфа петог, претпоследњег дела поеме. У њој се глагол расу$\bar{u} u$ не јавља али га призива њен први стих - $A$ üpax, све је йpax, каg gиг̄нем увис руку - неизбежно нас асоцирајући на израз расуйи, развеја$\bar{u} и$ üрах и уједно најављујући строфу чији је први стих А мир, свуg је мир, каg расием щитоо је било:

A йрах, све је йрах, каg gиг̄нем увис руку

и ирревучем, наg ировияним бряима и реком,

и неизмерно слабе, све тие тирещње, иитоо се вуку

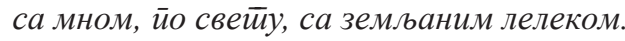

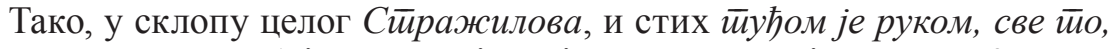
$\bar{u} о$ мени разасуйо добија сложенији и уједно прецизнији смисао. Као што прошлост песничког субјекта бесповратно нестаје, развејана као свело лишће, тако су све $\bar{u} y \bar{z} е$, дошле тек животом, разасуйе по њему и нестаће без трага, а остаће само оно о чему говоре последња два стиха: Знам, иолако ияем у јеgну йайюу gуг̄у/u, знам, йог̈нућу гллаву, кая лищће буgе жутио. ${ }^{32}$

Фигуре са глаголом расуйи (и његовим једнократним „двојником“ разасуйu) јављају се од другог до шестог дела Сйражилова, дакле у све три веће целине на које се природно дели поема Црњанског. Претходном анализом сам показао шта све одређује смисао оних међу њима које су праве метафоре ${ }^{33}$ на смисао утиче не само значење дате реченице и непосредни контекст него и претходне употребе исте речи, пре свега истински фигуративне али и све друге. У једном случају, како смо управо

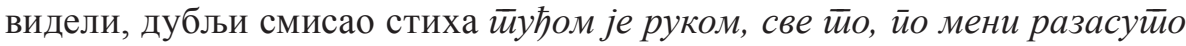
постаје јасан тек на самом крају поеме, кроз поређење са каснијим стихом А мир, свуд је мир, кая расием щийо је било.

31 И, наравно, из „Суматре“ и „Објашњења 'Суматре““, „Посланице из Париза“ и последњег од „Писама из Париза“, „Finistère“, објављеног у Новој Евройи у лето 1921. године. В. Crnjanski 1921b: 427-437.

32 Паралелизам између ових двеју строфа додатно је подвучен и очигледном паралелом и, знам, йог̄нућу г̄лаву, каg лищће буgе жуйо - и ириклоним г̄лаву, на оно, ийо ме чека.

33 А не само избледеле метафоре као расуйо лищће. 
У случају свих ових фигура, огрешења о семантичка правила која у читању једва примећујемо неутралишу се заједничким, сагласним деловањем других метафора с истом речју, како правих тако и избледе-

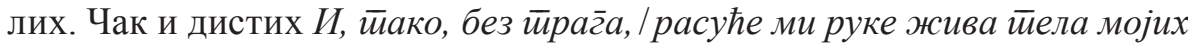

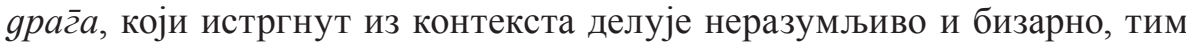
путем добија разумљив, асоцијацијама богат смисао. Али, на овај начин Црњански постиже и много више од тога да се наизглед бесмислена тврдња покаже смисаоно кохерентном. Посматране у целини, поготову када смо свесни читаве мреже њихових алузија и асоцијација, фигуре са глаголом расуйи имају прегнантан, нијансама богат смисао који измиче свакој коначној парафрази - смисао какав је тешко остварити не само у обичној прози него, осим изузетно, и у многим песничким жанровима. Мада досад нису биле посебно проучаване, метафоре и друге фигуре овог типа једна су од најважнијих новина које је у српску поезију двадесетих година унео модернизам, тачније она његова струја чији су главни представници тада били Црњански и Винавер. ${ }^{34}$

\section{IV}

Начин на који се неутралишу огрешења о семантичка правила може бити још сложенији, то јест у њега не морају бити укључене само метафоре (односно друге фигуре) с истом речју. Једна од најлепших фигура у целом Сйражилову - из шестог, последњег дела поеме - говори о миловању, као и завршни стихови „Суматре“, али не више у благо меланхоличном него у трагичном тону: 35

И, йако, без йуйа, и моје миловање, йо умирању, луйа

Огрешење о семантичка правила овде је очигледно: ако су речи употребљене дословно, моје миловање не може да лута, а још мање да то чини без йyйa и $\bar{u} о$ умирању. Па ипак, када прочитамо те стихове у њиховом непосредном контексту, ефекат кршења семантичких правила једва се осећа:

И, местио сребрних йруг̄a забрежја и река, сусрећем, као у сну, уморне мисли своје.

34 Фигуре ове врсте честе су код Винавера у првој половини двадесетих година, у песмама које су касније ушле у Чуваре свети $а$, али се оне код њега углавном међусобно повезују једноставније него код Црњанског. Типичан пример била би једна од најпознатијих песама ове збирке, састављена од трију катрена, где се метафора исте струк-

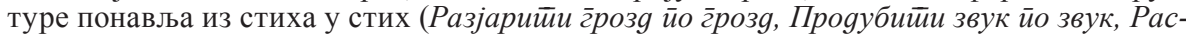

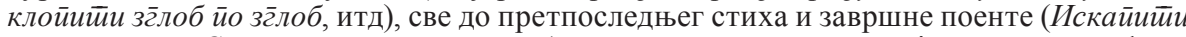
вир йо вир-Свих сущйина зрели мир): до смисла сваке од тих једанаест метафора можемо доћи само истовременим тумачењем свих њих.

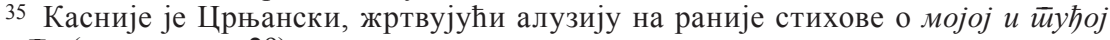
млаgостии (в. горе, нап. 29), изоставио $u$ на почетку другог стиха. 
A, наg итрешњама и млаяим вищњьма,

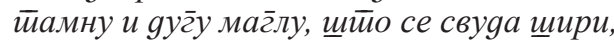

у животи иред нама,

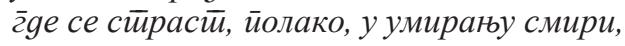

и чула уйокоје.

И, тиако, без реgа,

млаяости увијам миром снег̄ова и леgа.

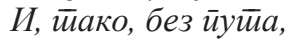

и моје миловање, ӣо умирању, луйа.

На крају прве строфе умирање се може односити на нестанак страсти или на дословно схваћену смрт (дакле, и смрт песничког субјекта), а исту двосмисленост налазимо и у завршном стиху, и чула уйокоје. У следећој строфи та се двосмисленост преноси у стихове $И$, йако без $\bar{u} y \bar{u} a, /$ м моје миловање, йо умирању, луйа. Али и њено постојање је готово неприметно, слично огрешењу о семантичка правила у изразу моје миловање. Да бисмо видели зашто је тако, морамо се вратити још неколико строфа уназад, до краја претходног дела поеме:

Луйам, јоми, витиак, са осмехом муйним, ирекрсииим руке, наg облачимма белим; али, йолако, саg већ јасно, слуйим gа умирем и ја, са духом йойамнелим, иециким, невеселим.

Овде је смрт песничког субјекта уведена као мотив недвосмислено и емфатично ( $g$ у умирем и ја,...), па само две строфе касније умирање не може а да се не односи на њу, што год још можда ова реч ту означава-

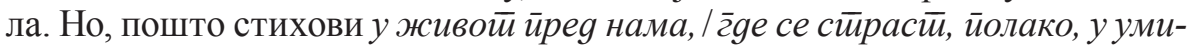
рању смири / и чула уйокоје свакако говоре и о нестанку страсти, умирање мора овде означавати и једно и друго, и гашење страсти и смрт субјекта. Међутим, то није обична двосмисленост, где иста реч може бити схваћена двојако, па да следствено томе реченица у којој се јавља добије једно или друго од двају сасвим неповезаних значења. ${ }^{36}$ Напротив, оба значења, фигуративно и дословно, најтешње су повезана: живот у којем се страст, йолако, гаси стварно је живот који се гаси и сам.

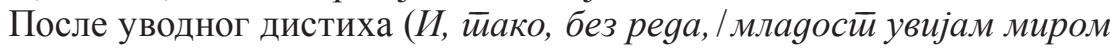
снег̄ова и леgа), који у супротном емоционалном кључу понавља суматраистичку слику с почетка поеме, ${ }^{37}$ то нам још једном кажу стихови

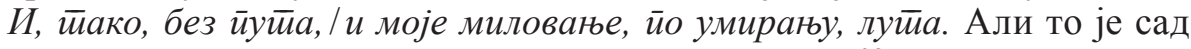
тврдња без временске ограде из претходних строфа, ${ }^{38}$ неопозива конста-

36 Као што Пребацио му је све губийке које су зајеgно найравили може да значи било Пренео је на њег̄а све г̄убитике... било Замерио му је све гуубийке...

37 саg, йлавим и гуустиим, / снегоом и леgом, смещећи се, мирим, / све шитоо се збива.

38 али, иолако, саg већ јасно, слуйим/gа умирем и ја... - уживой иреед нама, / се стирасти, йолако, у умирању смири... 
тација. Песничко „ја” чија се страст гаси себе у пуном смислу изједначава са њом: моје миловање мора се схватити као синегдоха за самог субјекта. Та синегдоха припремљена је и контекстом ширим од досад разматраног.

Сам глагол миловайи претходно је већ двапут био употребљен, и то оба пута метафорично, најпре у оквирној строфи четвртог, а затим и у једној строфи петог дела поеме:

Дрхииим, јоми, витиак, ов река и небеса, милујем ваздух, заяњом снагоом и наgом, али, свиснућу, йо и овgе слуиим, за гоомилом оном, јеgном, давно, млаяом, йоg сремским винограяом.

И йако, без йаме, gух мој, са мрачним воћкама, иокрива ме. И йако, без имена, истиом жалощћу милујем бряа невиђена.

На први поглед, ове две метафоре (милујем вазgух, заяњом снаг̄ом и наяом - исииом жалощћу милујем бряа невиђена) као да нису ни у каквој вези са синегдохом моје миловање у последњем делу поеме: суматраистички однос субјекта према природи, присутан и кроз директну алузију на завршне стихове „Суматре“, ${ }^{39}$ наизглед нема ничег заједничког са трагичном констатацијом и моје миловање, йо умирању, луйа. Али, ако се у самој „Суматри“ или „Посланици из Париза” суматраизам Црњанског ни на који начин не сучељава са смрћу, у Сйражсилову сигурно није тако. То врло јасно показује и сама оквирна строфа четвртог дела

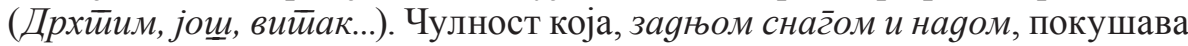
да одагна слутњу о смрти, а затим исйом жалощћу, не знајући им име, милује брgа невиђена, већ носи у себи клицу страсти која се гаси. Стихови И, йако без йуйа, / и моје миловање, йо умирању, луйа не би имали трагични смисао који имају да иза њих не стоји узалудан покушај да се сублимираном чулношћу (милујем вазgух - милујем брgа невиђена) обеснаже слутње о пролазности и нестанку.

Значењском богатству и прегнантности тих стихова доприноси и то што се повезују са четвороструким лутиам на максимално истакнутим местима у поеми, у оквирним строфама њеног првог, трећег, петог и шестог дела (Луйам, јои, витиак, са сребрним луком - Луйам, јои,

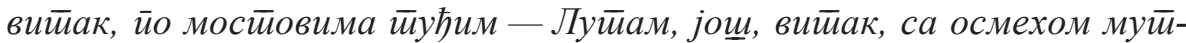
ним - Лутиам, јоми, витиак, са щайайом сиррасним). Луйам на почетку тих строфа, у складу с основним значењем овог глагола, описује трајнију активност без јасно утврђеног циља. Та се активност у следећем стиху

39 Имилујемо gалека брgа/ и леgене г̄оре, благ̄о, руком - истиом жалощћу милујем брgа невиђена. 
комбинује са представом неке метафорично одређене радње, којом се изражава расположење песничког субјекта: расиветиане тирещње, из засеgа, мамим - на мирисне реке, ирилежем, йа ћуйим - ирекрстиим руке, наg облацима белим - и оирресам чланке, смехом иреливене. Завршна три стиха, као контраст, ${ }^{40}$ садрже више или мање експлицитну слутњу песничког ,jа“ о сопственом крају. Све четири строфе тако пред-

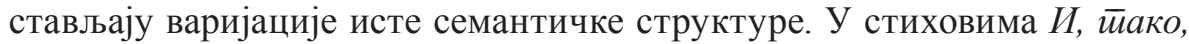
без йуйа, / и моје миловање, йо умирању, луйа од свега тога је остало само лутање по имагинарном простору умирања.

Свако ко пажљиво чита Сйражилово мора осетити трагику контраста између строфа о лутању и шкртог, сведеног дистиха где је моје миловање синегдоха за песничког субјекта. Без обзира на слутње које га обузимају и које узалуд покушава да одагна, у строфама о лутању субјект је још сав прожет чулношћу и лепотом онога што је доживео и што још увек доживљава: свако његово луйам открива нам једно још увек витално „ја“, потпуно свесно себе и света који га окружује. Те виталности и свести о околном свету нестаје када субјект са̂м изједначи себе са страшћу која се гаси, па зато више не говори лушиам него себе означава фигуром којом се прећутно одриче сваке праве потраге за уживањем.

Строфа којом почиње последњи део поеме зато има донекле друкчији смисао када се поново јави као њен завршни акорд:

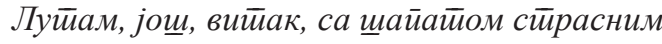
и оирресам чланке, смехом иреливене,
али, иолако, иирагоом својим, слуииим,
йищина ће сииићи, каg све ово свене,
и мене, имене.

На почетку последњег дела, та строфа као да само варира претходну, коју сам већ навео (Луйам, јоми, витиак, са осмехом муйним...). ${ }^{41} \mathrm{Kaо}$ и ту, слутња краја уравнотежена је активним држањем субјекта (ирекрстиим руке, наg облацима белим - и ойресам чланке, смехом иреливене): пред њим, бар наизглед, још нису затворене све животне могућности. Али, на самом крају поеме, више нема никакве сумње да су те могућности илузорне: од активног ,,j" остало је само моје миловање које бесциљно луй $а$ свесно блиске смрти и, у следећој строфи, трагична резигнација ( А мир, свуg је мир, кая расиемм щитоо је било..). Додуше, два закључна дистиха последњи пут нас враћају суматраистичком осећању живота:

И, йако, без мора,

ирелићу животе нащи, зорама Фрущких Гора.

И, йако, без ӥића,

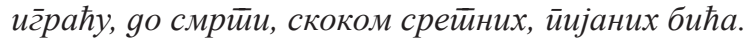

40 Осим у трећем делу, где завршни стихови говоре о завичају.

41 В. горе, стр. 215. 
Али, претходни стихови (на цеео јеgан крај, са ког̄ се вино слило,/

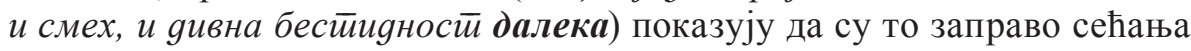
пројектована у имагинарну будућност. Замишљене радње само су начин да се, бар као фантазам, оживе одсутни завичај и угашена страст. Завршна строфа тако добија неопозиво трагичан смисао какав није имала на почетку последњег дела поеме. Тищина ће стиићи, каg све ово свене, / и мене, и мене сада значи само смрт, исказану не директно као пре ( gа умирем и ja,...), него метонимијом, која смрт именује њеним последицама. Она ће стиићи као тичщина коју не ремети ни говор субјекта о себи, ни говор других о њему, као коначно ћутање.

Као и у претходном примеру фигура са глаголом расуй $u$, видимо да је смисао дистиха И, йако без йуйа, / и моје миловање, йо умирању, луй $а$ - једва разумљивог ако га посматрамо самог по себи - добрим делом одређен како контекстом неколико претходних строфа тако и заједничким деловањем више метафора које се јављају раније у поеми. Међутим, у овом случају то нису увек метафоре с истиом речју. Смисао овог дистиха открива нам се тек посредством фигуративних али и дословних употреба његових $\bar{u} р и ј у$ кључних речи или, тачније, лексема: миловање/милујем, умирање/умирем, лушиа(м). Изразита огрешења о семантичка правила која се у њему јављају неутралишу се сагласним деловањем како претходних метафора, тако и претходних исказа где су неке од тих речи (луйам, умирем) употребљене дословно.

Чини ми се да су ова два примера довољна да покажу како треба одговорити на раније постављено питање о односу између сплета фигура које се провлаче кроз читаво Сйражилово и променљивог сучељавања двају различитих егзистенцијалних расположења на чијој се позадини конституише смисао целе поеме. Да средишне фигуре Сйражилова немају смисаону истанчаност и богатство које прави читалац поезије осећа чак и кад није у стању да тај осећај преточи у колико-толико експлицитне формулације, то сучељавање могло би да делује сувише интелектуалистички, па чак и да нам се учини да је као тематска окосница поеме пре наметнуто књижевно-историјским разлозима него што проистиче из самог текста. Међутим, сам смисао средишних фигура Сїражилова уверава нас да није тако. Када су тачно протумачене, у складу с особеним начином на који се Црњански служи фигуративним језиком, оне нам недвосмислено откривају колебање песничког „ја“ између њему природних суматраистичких осећања и све јасније свести о пролазности и смрти. Говорити о сучељавању тих двају егзистенцијалних расположења у вези са Сйражиловом није последица жеље да се поема Црњанског доведе у везу са његовим другим текстовима („Објашњење 'Суматре'“, „Посланица из Париза“, „Finistère“); то је само сажет израз онога што нам, са непоновљиво личним смисаоним акцентима, говоре средишне фигуре саме поеме. 
Погледајмо, на крају, и један пример који се унеколико разликује од претходних:

И, йако, без врења,

за мном ће животи у йрещње gа се мења.

Огрешење о семантичка правила овде је приметно и при читању а не само када посматрамо стихове истргнуте из контекста. Оно ипак не ствара суштинске тешкоће читаоцима који боље познају рано стваралаштво Црњанског, јер они овај дистих - можда и не разумевајући га до краја - одмах препознају као израз суматраистичког осећања живота. На то их упућују сви претходни стихови Сйражилова где се помињу трешње, ${ }^{42}$ као и сам непосредни контекст овог дистиха:

Јер љубав ће моја йомещайи йајно,

йо светиу, све йойоке и зоре,

и сиуустииии на животе, веgро и бескрајно,

и коg нас, небо и сенку Фруике Горе.

И, йако, без звука,

смех ће мој йаgайи, са небесног лука.

И, йако, без врења,

за мном ће животи у йрещње gа се мења.

Ове две строфе, пета и шеста у четвртом делу поеме, једино су место у Сйражилову где изгледа да суматраистичко осећање бар на тренутак побеђује свест о пролазности. Јер којим почиње први катрен као да одговара на претходне стихове - И, йако, без тираг̃a, / расуће ми руке жива иела мојих gраг̃a - покушавајући, ако не да им припише друкчији смисао, а оно бар да обеснажи све што из њих проистиче као закључак. Жива

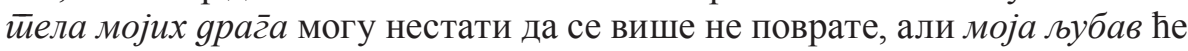

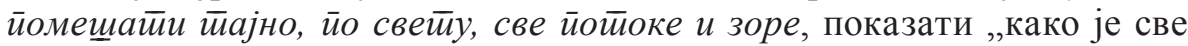

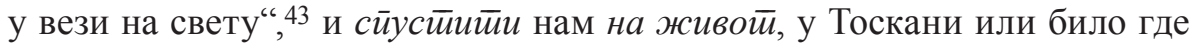
другде, небо и сенку завичаја. ${ }^{44}$ Шта би то могло да значи, говори нам следећа строфа, кроз оксимороне који се тичу смеха и йрещаға, двеју речи најтешње повезаних у Сйражилову са суматраистичким осећањем живота.

42 Са алузијама које садрже не само на „Суматру“ и „Објашњење 'Суматре““ (в. горе, стр. 205-207), него и на „Посланицу из Париза”, нарочито на њене прве две

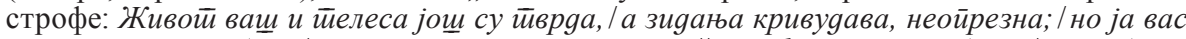

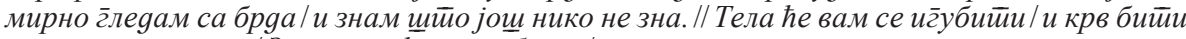

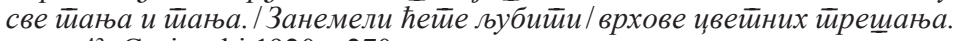

${ }_{43}$ Crnjanski 1920c: 270.

44 Да је Фрущика Гора овде синегдоха за завичај, јасно је на основу првих двеју строфа поеме. 
У целој поеми, чулност и лепота доживљаја, животна ведрина и радост многоструко су присутне и о њима се говори на више начина, и фигуративно и дословно. Али од тих начина као да се посебно повлашћују два, један где се о њима говори метонимијски, посредством смеха, и дру-

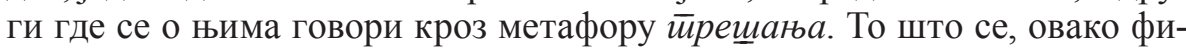
гуративно употребљене, речи смех и йрещње једини пут у целој поеми јављају заједно, даје овој строфи посебну тежину: суматраистичко осећање живота, исказано колико-толико дискурзивним путем у „Објашњењу 'Суматре'“, а низом песничких слика и лирском фабулом у самој „Суматри“ и „Посланици из Париза“, овде је изражено кроз две фигуре које као да смишљено скрећу пажњу на себе, опирући се ма и приближној парафрази више него друге средишне фигуре Сйражилова. Чак и кад учинимо што је могуће да се дође до смисла тих стихова, они бар унеколико остају непрозирни.

Као што је често случај са добрим метонимијама, реч смех се у Сйражилову употребљава и фигуративно и дословно. На самом почетку поеме реч је употребљена фигуративно (гgge ћy cмex, üog јаблановима самим, /ga сахраним), док се у две суседне строфе четвртог дела јавља

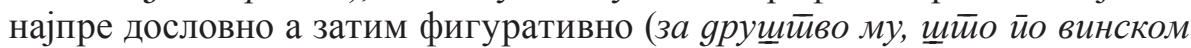
меху, / свело лищће расу... / иррескачући, иррви йуй, иооиоке, у смеху.// А, местио свог̄ живойа, знам gа, йо вияику, / йај смех расух... ). У дистиху И, йако, без звука, / смех ће мој йаgайи, са небесног̄ лука, смех има исти метонимијски смисао као у првој строфи поеме: тамо, ${ }^{45}$ као и овде, $с м е х$ се односи на чулност и лепоту доживљаја, животну ведрину и радост, које песничко „ја“ најпре слути да ће изгубити, а затим на тренутак поверује да ће, необјашњивим посредством љубави, њима бити прожет чи-

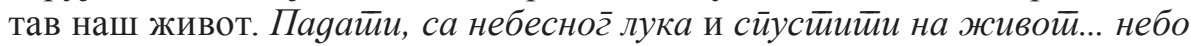
и сенку Фрущке Горе напоредни су покушаји да се дочара нешто што измиче рационалном разумевању, у шта треба поверовати да би се разумело. Без звука као да нам управо то говори: чулност и лепота, ведрина и радост појавиће се у нашем животу на досад незамислив, необјашњив начин, као што би нам изгледао необјашњив безгласни, а не само из неког разлога нечујни смех.

Сличан је, мада још парадоксалније формулисан, смисао метафоре у другом дистиху ове строфе: И йако, без врења, /за мном ће живой y йрещњ gа се мења. У природном врењу трешње се, као и друго воће, преображавају саме, без спољног подстицаја, мењајући се у друкчију супстанцу, а ова затим служи људској намени, која нема никакве везе са оним што је трешња као дрво и плод у свету природе. Колико год неупућенима могао изгледати необичан, унутрашњи процес врења рационално је објашњив и не крије у себи никакву тајну. Песничко „ја” каже

45 Када први пут прочитамо уводну строфу Сйражилова, то наравно не мора бити јасно, али се разјашњава у даљем читању. 
без врењ $а$, јер оно што осећа да ће наступити необјашњивим посредством његове љубави и прожети изнутра читав наш живот - чулност и лепота, ведрина и радост, а тирещъье су за све то метафора - није рационално схватљиво. ${ }^{46}$ Bреґье је, дакле, употребљено као синегдоха за било какав рационално објашњив процес који се одвија унутар неке ствари или појаве и даје одређен резултат: ${ }^{47}$ суматраистичко осећање живота, разуме се, потпуно искључује идеју да се људски живот може мењати на тај начин.

Исто је тако, можемо додати, само делимично схватљиво (позивањем на нежну лепоту трешања у цвету, на руменило и укус зрелих трешања, итд) зашто је Црњански, у Сйражилову и другде, изабрао управо трешње 48 и дао им овако повлашћено место у свом стваралаштву. Али му је неоспорно пошло за руком да створи од њих симбол којим ће, у врхунском периоду своје поезије, негде од „Суматре“ до поеме Сербиа, изразити своје осећање живота.

Нигде то није тако јасно као у Сйражилову. Сам дистих И йако, без врења, / за мном ће животи у йрещње gа се мења једна је од кључних фигура поеме, а начин на који се трешње појављују у свакој од трију већих целина тачно одсликава тренутни однос суматраистичког осећања живота са свешћу о пролазности и слутњом сопственог краја. У првој целини трешње се само доводе у везу са завичајем и чулношћу, како у уводној строфи (расиветиане тирещње, из засеgа, мамим; / али, иза гоора, завичај већ слутиим...), тако још експлицитније нешто касније: А... веселосии мојој, чилој и йомамној, /gве засйале, болне gојке не gају, /ga cе, гласним криком, баии иоо иррещњама, / ийо ми остиаgоще у завичају. У другој целини најпре се у сећањима на завичај, дубоко прожетим чулношћу, заједно помињу вищње и йрещњье и смех, 49 а затим долазе строфе (Јер моја ће љубав иоомещатии тиајно...// И йако, без звука...) у којима суматраизам као да бар на тренутак побеђује свест о пролазности и смрти. Најзад, у завршној целини, после уводне строфе петог дела (Луйам, јои,

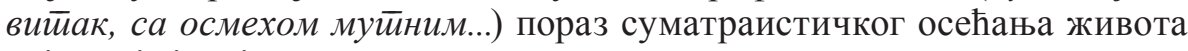
најављује још једна парадоксална слика са трешњама:
A йрах, све је йрах, каg gиг̄нем увис руку
и йревучем, ная ировияним бряима и реком,
и неизмерно слабе, све иеме тирешњье, ийо се вуку

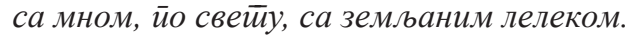

Овде су йрещње поново метафора, али не више за чулност и лепоту доживљаја, животну ведрину и радост, као у дистиху И йако, без врења, /

46 Нити га песничко ,jа“ односно његов творац, аутор Се̄ражилова, сматра таквим.

47 Овај тип синегдохе где се фигуративно употребљеном речју не означавају, рецимо, сви процеси одређене врсте него било који од њих могли бисмо звати йарӣийивним.

48 И, понегде, заједно с њима вишње.

49 У стиховима које сам већ цитирао; в. горе, стр. 211. 
за мном ће животи у йрещњ gа се мења, него само за сећања на њих. Успомене песничког ,ja”, неизмерно слабе, гасе се и нестају, постајући и саме йрах, док се вуку/са мном, йо свейу, са земљаним лелеком: ова слика, на друкчији и много посреднији начин, садржи исту трагичну слутњу као директни исказ али, йолако, саg већ јасно, слуйим/gа умирем и ја, са gухом йойамнелим, / иеешким, невеселим.

Сличне смисаоне модулације јављају се и са речју смех. Паралелизам је потпун ако, у првој од трију већих целина у поеми, узмемо да реч веселос $\bar{m}^{50}$ наставља исту значењску нит започету поменом смеха на са-

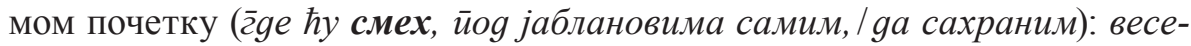

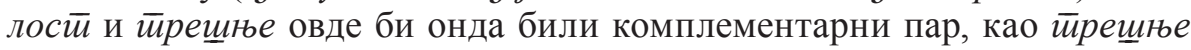
и смех у уводној строфи и на другим местима у поеми. У другој већој целини, видели смо, речи смех и йрещње употребљавају се како дословно тако и фигуративно: фигуративно употребљене, оне најпрегнантније у целом Сйражилову изражавају суматраистичко осећање живота. Најзад, у последњој од трију већих целина, где йрещње више нису метафора за чулност и лепоту, ведрину и радост, већ само за сећања на њих, и смех се јавља у контексту сећања: видели смо да се стихови на цео јеgан

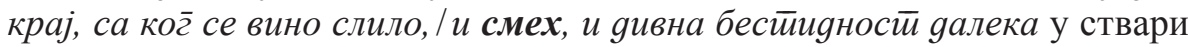
тичу сећања пројектованих у имагинарну будућност. ${ }^{51}$ Тек на самом крају, кад нас последња строфа поеме враћа првој, и речи смех враћа се

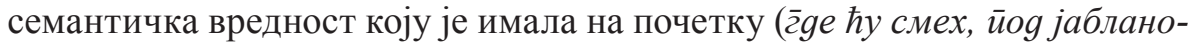
вима самим, / gа сахраним - и оирресам чланке, смехом ирреливене).

Као и у претходна два примера, смисао стихова који садрже огрешења о семантичка правила и овде је одређен како значењем дате реченице и непосредним контекстом, тако и заједничким, сагласним деловањем других фигура с истом речју (смех, йрещъье) односно исказа где су те речи дословно употребљене. Међутим, у стваралачкој уобразиљи Црњанског ове речи су биле присно повезане с његовим осећањем живота, тако да у његовој поезији оне готово увек имају ауру суматраистичких асоцијација. То може да створи утисак да је смисао стихова $И, \bar{u} а к о$, без звука, / смех ће мој йаgайи, са небесног̄ лука/И йако, без врења, /

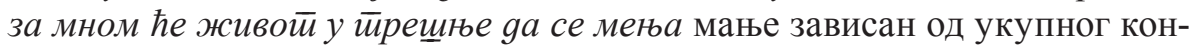
текста Сӥражилова него што је то случај са другим средишним фигурама. И тесна смисаона веза између двају дистиха, и њихова веза са непосредним и ширим контекстом показују колико је тај утисак погрешан. Сплет фигура које се провлаче кроз текст Сйражилова од прве до последње строфе исто је тако беспрекорно уобличен као његова бриљантно остварена и лако уочљива трострука организација — ритмичка, строфичка и реторичка.

50 У горе цитираним стиховима $A . .$. веселосйи мојој, чилој и йомамној... из другог дела Сӥражилова.

51 В. горе, стр. 217-218. 


\section{VI}

Моја намера није била да исцрпно размотрим употребу фигуративног језика у Сйражилову. Желео сам само да осветлим њене кључне аспекте, оне за које ми се чини да су особени за песничку семантику Црњанског и уједно најтешње повезани са смислом и лепотом његове поеме. Због тога сам се усредсредио на посебну врсту фигура коју је Црњански (заједно са Винавером) не само увео у српску поезију него, могли бисмо рећи, у Сйражилову и развио до њених крајњих изражајних могућности. Код Винавера овакве фигуре налазимо у краћим песмама

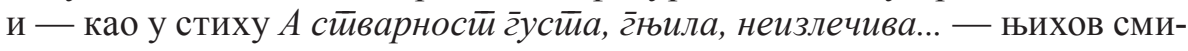
сао често је одређен сагласним деловањем више једноставних метафора

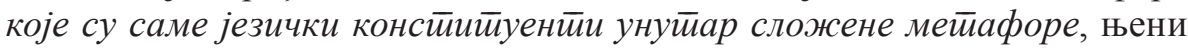
саставни делови. Такве сложене метафоре у Чуварима свешиа најчешће „стају” у границе једне строфе, али понекад се протежу и кроз више строфа, као у песми Разјарийи г̄розg йо г̄розg коју сам већ поменуо као пример Винаверовог поступка. ${ }^{52}$ У случајевима ове врсте тумачење се превасходно тиче непосредног контекста: сложена метафора нам се разјашњава тумачењем једноставнијих метафора које су уједно њени саставни делови, и тако до кохерентног смисла долазимо углавном не идући даље од контекста (стиха, строфе, више строфа) где се и јавља огрешење о семантичка правила. Овде претходне употребе неке кључне речи, ако их уопште има у датој песми, тешко да могу играти битнију улогу; смисао сложене метафоре откривамо преко смисла и међусобних односа једноставнијих метафора које су њени саставни делови и по правилу творе затворену значењску целину.

Средишне фигуре у Сйражилову никада немају овакву једноставну структуру. Њихов смисао увек је одређен и сагласним деловањем $p a-$ нијих фигура с истом речју, што значи да шири контекст релевантан за тумачење дате фигуре по правилу обухвата више строфа из различитих делова поеме која има укупно 216 стихова. Ако узмемо у обзир да на њен смисао утичу и раније gословне употребе исте речи (ако их има), а понекад и фигуративне односно дословне употребе једне или више gруг̄ux речи, јасно је да свака средишна фигура у Сйражсилову на свој начин доприноси дубљем јединству целе поеме. То нам показује и једна чињеница о којој је досад било речи из других разлога. Када у читању дођемо до стихова као што су А мир, свуg је мир, каg расйем щиио је било

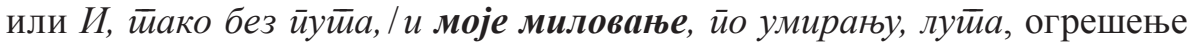
о семантичка правила је једва приметно, колико год иначе било стварно. Али овде није посреди само то да нам је тумачење речи расием односно миловање знатно олакшано њиховим ранијим јављањем у поеми. ${ }^{53}$ Обе

52 В. горе, нап. 33.

53 А, у другом случају, и ранијим јављањем речи умирање/умирем и луйа(м). 


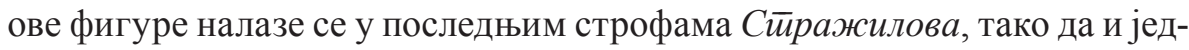
на и друга сажимају у себи низ смисаоних варијација, углавном фигуративно исказаних, које се тичу пролазности односно сопствене смрти. У контрапункту са другим средишним фигурама, и „суматраистичким” и онима о којима овде нисам говорио, 54 те варијације нам откривају потпуно особен однос према смрти и пролазности, који у равни осећања измиче сваком покушају свођења на једноставне прозне формулације. Све средишне фигуре Сйражилова имају ово значењско богатство које потиче и од тога што у себи сажимају низ претходно исказаних смисаоних нијанси, и од тога што се смисаоно сучељавају са другим фигурама, пре свега онима супротног емоционалног тона. Захваљујући управо тој околности, поема Црњанског поседује дубље јединство које тешко да је остварљиво неким другим путем: она има препознатљиво јединствен смисао, несводљив на било какву прозну парафразу, који пре свега дугује варирању, преплитању и сучељавању својих средишних фигура.

Има поштовалаца Црњанског који би на ово вероватно са скепсом казали да за јединство Сїражилова довољно јамчи његова ритмичка, строфичка и реторичка организација, мајсторски остварена до последњег детаља, комбинована са кохерентном лирском фабулом, која нигде не изневерава читалачка очекивања. Не доводећи нужно у сумњу овде изнету анализу средишних фигура у Сйражилову, они би могли рећи да она ипак нема значај који сам јој управо приписао. На крају крајева, једно је тврдити а друго доказати. Чиме се може образложити ова далекосежна тврдња о значају фигуративног језика у Сйражилову?

На то питање било би далеко теже одговорити да нам у томе посредно није помогао сам Црњански, својом раном и мало познатом песмом „Ново поколење“, коју овде наводим у целини: 55

Наме је лиие блеgо без знака, као месеи наg воgама бескрајним, али са колуйом муйним и йајним на очима, сјајним као круна лака.

Бол јеgног̄ јаблана

вище нас йекне но свеле груди наших драг̄ана. А кая неко щийо ииужно рекне о млаяосиии ил животеиу бедном,

54 То се посебно односи на фигуре са речима небо, небеса, небесни, при чијем тумачењу би свакако требало узети у обзир везу Сйражилова са „Посланицом из Париза“. И у Сёражилову и у „Посланици из Париза“ почетни импулс за уобличавање тих фигура као да је било познато место из „Објашњења 'Суматре'“: „,[И] као у некој лудој халуцинацији дизао сам се у те безмерне јутарње магле, да испружим руку и помилујем далеки, високи Урал, мора индијска, куд је отишла румен са мога лица...“

55 Црњански 1920a: 341-342. 
наши осмех са ситрашћу болном али меgном,

засйи, у ирройланку јеgном.

И местио жена са йихим дрхӣанем

небо је наша бољка,

мами нас, иайуће ситрасно и меко:

gа се оg румени наших усана

нег̄gе gалеко,

йуна јеgног̄ бисера слана,

расииуче једна щикољка.

И тиако без моћи

несретини смо и љубљени ко ноћи.

И йако без снагее

влаяамо свейом, у јесени благ̄e.

Помешали смо љубав и облаке,

а суябу нашу са лиићем и биљем.

Горке законе у осмехе йужне и лаке,

шийо све кияају стирашћу и миљем.

И йако без наgе

местио у нас верујемо у иуме млаgе.

И йако без моћи

несрет̄ни смо и љубљени ко ноћи.

Наме је лице блеgо без знака,

као месеи наg воgама бескрајним,

али са колуйом муйним и йајним

на очима, сјајним

као круна лака.

Ако узмемо у обзир датум њеног објављивања, ова песма драгоцено је сведочанство о настанку Сйражилова и стваралачком процесу Црњанског. Годину и по дана пре него што је, за време боравка у Тоскани у пролеће 1921, написао Сйражилово, а пуне две године пре него што ће поему објавити у целини, Црњански је имао више-мање уобличен образац ритмичке, строфичке, а донекле и реторичке организације коју ће шест пута поновити у Сйражилову. Већ на први поглед пада у очи да „Ново поколење“ има исти број, карактер и распоред строфа као сваки од шест делова Сйражилова; једина разлика је у томе што се сви стихови осим једног римују, па се не осећа каснија склоност Црњанског ка асиметричној рими. ${ }^{56}$ Интонационо рашчлањавање унутар појединих стихова није тако изразито као у Сйражилову, али је у основи слично; реторичка организација је друкчија утолико што је песма у првом лицу

56 В. Црњански 1922b: 285. У Сйражилову прва и друга строфа сваког дела има распоред рима $(a, b, c, b, b)$ односно $(a, b, a, b, c, d, c)$, док у „Новом поколењу“ имамо $(a, b, b, b, a)$ и $(a, b, a, b, c, c, c)$. 
множине а не једнине, али многи важни реторички обрти су потпуно исти. На пример, четврта и шеста строфа имају исту карактеристичну

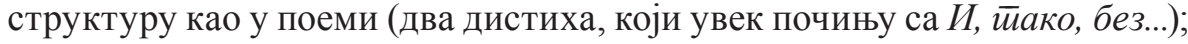
трећа строфа, као и у Сйражилову, почиње са И местио... и на сличан начин развија ту синтаксичку конструкцију; пета строфа, као неколико одговарајућих строфа у поеми, има тежину констатације с општим важењем; и, last but not least, последња строфа без измена понавља прву.

Упркос свим тим сличностима, могло би се рећи да „Ново поколење“" пре најављује Сӣражилово у техничком него у песничком погледу: средства су ту, али нити су употребљена на прави начин, нити је јасно како би то требало учинити. Истанчаност ритма и емоције коју имају „Суматра“ и „Посланица из Париза“, а поготову Сйражилово, недостижна је за песника „Новог поколења“. Његови покушаји да изрази своје осећање живота немају ни дубоку проживљеност „Објашњења 'Суматре'“, ни поетске квалитете „Суматре“" и Сйражилова. Многи стихови - Наше је лище блеgо без знака или И йако без моћи/несрейни смо и љубљени ко ноћи - толико су неспретни да је више него очигледно зашто Црњански никада није прештампао „Ново поколење“.

Али управо таква, неспретна и недоречена, ова песма открива нам нешто важно о Сйражилову. Њена ритмичка, строфичка и реторичка организација довољно је блиска поеми Црњанског да нам покаже колико је неуверљив сваки покушај да се било за ту организацију саму, било за њу комбиновану са лирском фабулом, вежу дубљи квалитети Cūpaжилова. Ни право јединство поеме, ни њена лепота не могу се објаснити на овај начин. Тек заједно са читавим сплетом средишних фигура и других песничких слика ови фактори имају ону тежину која им се често приписује.

Тврдња коју сам управо изнео само наизглед противречи ономе што сам горе рекао о дубљем јединству и јединственом смислу Сйражилова, доводећи обоје у везу са варирањем, преплитањем и сучељавањем средишних фигура. ${ }^{57}$ Средишне фигуре Сйражсилова, како их ја схватам и како сам о њима говорио, не постоје изван песничког текста у којем се

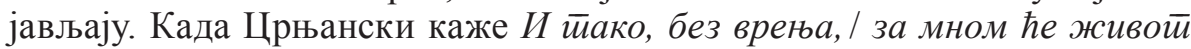
y йрещъ gа се мењ $а$, његова фигура није исто што и нека прозна парафраза, рецимо „И, тако, без врења, живот ће за мном да се мења у трешње“. Није реч само о томе да прозној парафрази недостају ритмички и мелодијски квалитети стихова. Метафора и њој сродне фигуре тумаче се у равни смисла који се саопштава у некој појединачној прилици, а не у равни апстрактног реченичног значења. ${ }^{58}$ Фигура у стиховима Црњанског има одређен смисао на месту где се јавља у поеми а не као слика апстрахована из текста Сӣражилова о чијем значењу можемо

57 В. горе, стр. 223-224.

58 УП. горе, стр. 204. 
да говоримо независно од њеног контекста. Са фигурама у поезији не поступамо као са максимама и афоризмима: када Ларошфуко каже „Лицемерје је признање које порок одаје врлини“, 59 предмет тумачења је искључиво значење његове реченице а не смисао који она може имати у некој појединачној прилици. У поезији је увек обрнуто.

Сплет средишних фигура и других песничких слика у Сйражилову неодвојив је од троструке организације поеме у којој свака од тих фигура и слика има своје место. Отуда, тврдити да дубље јединство и јединствени смисао Сӣражилова пре свега проистичу из варирања, преплитања и сучељавања његових средишних фигура не значи рећи да у томе трострука организација поеме нема никаквог удела. Све те средишне фигуре истовремено су јединице унутар строфичке и реторичке организације поеме, и само су као такве подложне тумачењу које нам открива како доприносе јединственом смислу Сйражилова. Оне утолико припадају оној „видној и за једну лирску поему заиста монументалној архитектури“ Сёражилова о којој је с правом говорио Марко Ристић. 60 Али, својим посебним доприносом оне истовремено изнутра преображавају ту „архитектуру“, чији је образац већ био јасно оцртан у „Новом поколењу“, дајући јој непоновљиву лепоту коју препознају сви прави читаоци српске поезије.

Изузетном песничком интуицијом Црњански је у неком тренутку осетио да би строфичка и реторичка организација која се показала сасвим неприкладна за прву верзију суматраистичког манифеста у стиху ${ }^{61}$ могла да послужи друкчијем и много амбициознијем циљу. Тај циљ био би неостварљив без сложене фигуративности која се провлачи кроз свих шест делова његове поеме: без ње, са сликама и метафорама попут оних у „Новом поколењу“, вероватно би било неког основа за познату и треба ли рећи? - потпуно неодрживу оцену Миодрага Павловића да је у Сйражсилову Црњански „предуго варирао и понављао један музички образац“".62

Критичарима и историчарима књижевности који су писали о поезији Црњанског углавном је промакло каква је улога фигуративног јези-

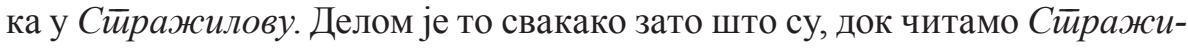
лово, огрешења о семантичка правила врло често једва приметна, па нам се не чини да се на њима треба посебно задржавати. Одатле је само корак до идеје да песму у којој уживамо и која нам у читању не изазива никакве недоумице можда ни не треба подвргавати озбиљнијој анализи. Али, ако је Т. С. Елиот био у праву када је рекао да „разумети једну песму и уживати у њој из правих разлога излази на исто“, ${ }^{63}$ а уверен сам да јесте, та је

59 L'hypocrisie est un hommage que le vice rend à la virtue.

60 В. горе, стр. 201.

61 То јест, за оно што је касније постигао „Посланицом из Париза“.

62 Павловић 1964: 62-63.

63 Eliot 1957: 115. 
идеја сасвим погрешна. Сложимо ли се са Елиотом, анализа средишних фигура Стиражилова коју сам дао у овом поглављу неће бити само допринос бољем разумевању особене песничке семантике Црњанског: она ће нам истовремено омогућити да на нов и донекле друкчији начин уживамо читајући Сйражилово.

\section{ЛИТЕРАТУРА}

Којен Леон. Јакобсон: Поейика и мейрика. Београд: Народна књига, 1998.

Којен Леон. „Предговор“. Леон Којен (уред.). Три жива иессника. Расӣко Пейровић, Милан Деgинаи, Дущин Майић. Београд: Zepter International. 2020: V-XXIX.

Маретић Томо. Хомерова Илијаgа. Превео Томо Маретић. Београд: Српска државна штампарија, 1905.

Милошевић Никола. „Композиција и порука 'Стражилова'“. Дисово йролеће X (1973): $4-11$.

Павловић Миодраг. Анӣолог̄ија срӣског̄ йеснищӣива. Београд: Српска књижевна задруга, 1964.

Петров Александар. Поезија Црњанског̄ и срӣско йеснищйво. Београд: Нолит, [1971], 1988.

Поповић Радован. „Рана писма Милоша Црњанског“. Къижевносӣ 39 (1984): 1591-1603.

Црњански Милош 1920а. „Ново поколење“. Мисао I (1920): 341-342.

Црњански Милош 1920b. „Суматра“. Срйски књижевни глласник, н. с. I (1920): 262.

Црњански Милош 1920с. „Објашњење ‘Суматре'“. Срйски књижевни г̄ласник, н. с. I (1920): $265-270$.

Црњански Милош 1922а. „Стражилово“. Пуйеви I/2 (1922): 3-9.

Црњански Милош 1922b. „За слободни стих“. Мисао IV (1922): 282-287.

Crnjanski Miloš 1921a. „Poslanica iz Pariza“. Zenit I/ 4 (1921): 2.

Crnjanski Miloš 1921b. „Finistère“. Nova Evropa II (1921): 427-437.

Eliot T. S. 1957. On Poetry and Poets. London, Faber \& Faber.

Kojen Leon. „Dva pristupa metafori“'. Kojen Leon (ured.). Metafora, figure i značenje: zbornik teorijskih radova. Beograd: Prosveta, 1986: 7-17.

Ristić Marko. „Miloš Crnjanski“. Delo III/ 1 (1957): 772-780.

Searle John.. „Metaphor“. Searle John. Expression and Meaning, Cambridge: Cambridge University Press, 1979: 76-116.

Vinaver Stanislav. „Sonata — triptihon Rastka Petrovića“. Kritika II (1921): 256-257.

\section{LITERATURE}

Crnjanski Miloš 1920a. „Novo pokolenje“. Misao I (1920): 341-342.

Crnjanski Miloš 1920b. „Sumatra“. Srpski književni glasnik, n. s. I (1920): 262.

Crnjanski Miloš 1920c. „Objašnjenje 'Sumatre'“, Srpski književni glasnik, n. s. I (1920): 265270.

Crnjanski Miloš 1921a. „Poslanica iz Pariza“. Zenit I/ 4 (1921): 2.

Crnjanski Miloš 1921b. „Finistère“. Nova Evropa II (1921): 427-437.

Crnjanski Miloš 1922a. „Stražilovo“. Putevi I/2 (1922): 3-9.

Crnjanski Miloš 1922b. „Za slobodni stih“. Misao IV (1922): 282-287.

Eliot T. S. On Poetry and Poets. London: Faber \& Faber, 1957.

Kojen Leon. „Dva pristupa metafori“'. Kojen Leon (ured.). Metafora, figure i značenje: zbornik teorijskih radova. Beograd: Prosveta. 1986: 7-17.

Kojen Leon. Jakobson: Poetika i metrika. Beograd: Narodna knjiga, 1998. 
Kojen Leon. „Predgovor“. Kojen Leon (ured.). Tri živa pesnika. Rastko Petrović, Milan Dedinac, Dušan Matić., Beograd: Zepter International, 2020: V-XXIX.

Maretić Tomo. Homerova Ilijada. Preveo Tomo Maretić. Beograd: Srpska državna štamparija, 1905.

Milošević Nikola. „Kompozicija i poruka 'Stražilova'“, Disovo proleće X (1973): 4-11.

Pavlović Miodrag. Antologija srpskog pesništva. Beograd: Srpska književna zadruga, 1964.

Petrov Aleksandar. Poezija Crnjanskog i srpsko pesništvo. Beograd: Nolit, [1971], 1988.

Popović Radovan. „Rana pisma Miloša Crnjanskog“, Književnost 39 (1984): 1591-1603.

Ristić Marko. „Miloš Crnjanski“. Delo III/ 1 (1957): 772-780.

Searle John. „Metaphor“. Searle John. Expression and Meaning, Cambridge: Cambridge University Press, 1979: 76-116.

Vinaver Stanislav. „Sonata — triptihon Rastka Petrovića”. Kritika II (1921): 256-257.

\section{Leon Kojen}

\section{POETRY-SPECIFIC SEMANTICS IN SERBIAN MODERNISM: CRNJANSKI'S STRAŽILOVO}

\section{Summary}

This paper examines the use of figurative language in the long poem Stražilovo (216 lines) by Miloš Crnjanski, one of the leading Serbian modernist poets, and identifies for the first time the characteristic procedure by which Crnjanski, by subtly modifying the metaphorical import of the same repeatedly used word, gives to his metaphors an unsuspected richness of meaning. Published in 1922, the year of T. S. Eliot's The Waste Land, Joyce's Ulysses, Rilke's Duino Elegies, Mandelstam's Tristia and Pasternak's My Sister Life, Stražilovo has long been recognized by many critics and literary historians as perhaps the single most important poem of Serbian modernism. But others have felt that its strict stanzaic and rhetorical patterning, highly original though it is, makes it somehow deficient: thus Miodrag Pavlović, together with Vasko Popa the leading Serbian modernist poet of the nineteen fifties, had famously asserted in 1964 that in Stražilovo Crnjanski ,,has repeated and varied for too long the same musical pattern". The argument of this paper shows why Pavlović's claim is rightly felt to be unconvincing by anyone who appreciates properly Crnjanski's poem. Its strikingly original metaphorical patterning accounts for more than its subtlety and richness of meaning: it is also a powerfully unifying factor as the reader follows the ultimately tragic trajectory of its protagonist, the "I" whose self-examination might be said to constitute the lyrical plot of Stražilovo.

Key words: Poetry-specific semantics, Miloš Crnjanski, Stražilovo, figurative language, metaphor. 